\title{
A DESCRIPTIVE STUDY TO ASSESS THE AWARENESS AND ATTITUDE REGARDING FEMALE FOETICIDE AMONG ELIGIBLE COUPLES AT SELECTED RURAL AREA OF JODHPUR
}

\author{
${ }^{1}$ Suresh, ${ }^{2}$ Rohit Kumar Chouhan \\ ${ }^{1}$ Lecturer, K.S. Memorial College of Nursing, Jodhpur \\ ${ }^{2}$ Community Health Officer, Govt. of Rajasthan
}

Article DOI: https://doi.org/10.36713/epra7795

DOI No: 10.36713/epra7795

\begin{abstract}
INTRODUCTION: Female foeticide is one of the most nefarious crimes on this earth, perhaps what detestable is that the people who commit crime belong to educated class. Some of the worst gender ratio gross violation's right is founding south and East Asian countries such as India and china. Numerous scholars have observed that the latest advances in modern medical sciences - the tests like Amniocentesis and Ultrasonography which were originally designed for detection of congenital abnormalities of the foetus are being misused for knowing thesex of the foetus with the intention of aborting it if happens to be that of a female.

AIM OF THE STUDY: Assess the awareness regarding female foeticide among eligible couples.

METERIAL AND METHOD: A descriptive study was carried out to assess the awareness \& attitude of 100 eligible couple selected by purposive sampling, who were eligible couple in rural area in Jodhpur Rajasthan were assessed by using a structured knowledge questionnaire and analyzed by using descriptive and inferential statistics were used for data analysis.

RESULT: The finding of the study shows that majority (54\%) of the sample had average awareness, followed by $29 \%$ had poor awareness and remaining (17\%) sample had good awareness regarding female foeticide. The finding of the study shows that majority (35\%) of the sample had negative attitude followed by $28 \%$ had positive attitude, $20 \%$ had strongly negative attitude and remaining (17\%) sample had strongly positive attitude regarding female foeticide. However, the majority of the demographic variables such as age of husband, education of husband, education of wife, monthly income of family, occupation of husband, occupation of wife and source of information of the samples indicates significant association with level of awareness and attitude regarding female foeticide except age of wife, religion, and type of family.

CONCLUSION: It can be concluded that eligible couple have average awareness regarding \& negative attitude regarding female foeticide as per current research recommendations. They require education and to enhance their awareness \& attitude regarding female foeticide
\end{abstract}

KEY WORDS: Awareness, Attitude, female foeticide, Eligible couple.

\section{INTRODUCTION \& BACKGROUND OF THE STUDY}

"Save a girl child, as a girl is Gold ornament of family 'As we keep gold in safe condition it shines more, if we save girls, they shine but we have to save them to shine."

Male and female is the pillar of the society and they are inevitable for the survival of society.
They perform explicit social role and function for society so that social structure. One of the most significant social functions is that they systematized family by relation of marriage which is the vital social structure and primary group as well as center of society. The dynamic social function of family is procreation and socialization of newly birth child which is essential requisite for the existence of 
society. It is expectation that the proportion of male and female child must be equal and some extent it to be natural. ${ }^{2}$

The term female foeticide means killing the female foetus in the mother's womb. The practice has been followed in India for last five decades, a country that once described its women as goddesses. For this reason, Indian women will soon get extinct. Surprisingly, the most active part is being played by the women themselves - why? Just for the mere want of a boy, mothers don't feel bad in strangulating their daughters in their wombs. Can anyone be crueler? Female foeticide is perhaps one of the worst forms of violence against female girls where a female is denied her most basic and fundamental right i.e. "The right to born". India is perhaps the only civilization that worships God in woman-form, but still doesn't stop many countrymen from killing their own daughters. Gone are the days, when the birth of a girl child in the family was greeted as the arrival of "Lakshmi" the Hindu goddess of wealth. Now due to change in societal attitude, girls are seen as a burden, it may be because they have to be protected and provided with large sums of money for wedding and dowries. This "modern" cultural preference for sons (who bring income in the form of dowries) has begun to seriously skewed sex ratios in the country. This strong preference for sons is expressed by resorting to large-scale female foeticide. ${ }^{5}$

Female foeticide is commonly practiced across the Rajasthan and female infanticide is also common especially in districts the Jaisalmer. The archaic social structure has always given preference to male over female in the state. Unit recent times, the state had high mortality rate of 445 per 100,000 live births. The birth of a girl child meant bad news; mainly due to the hefty dowry system prevalent in the state. ${ }^{8}$

The provisional population totals of NCT of Delhi for 2011 put the sex ratio in Delhi/NCR at 866 females per 1000 male (census 2011). Even though the figures show a marked improvement since 2001 when the sex ratio count was 821 females per 1000 (census 2011), these statistics suggest prevalence of sex selective abortion on large scale. Gender preference enshrined in social perception is thought to be a major cause of sex selective abortions. sex ratio indicated the proportion of the number of men women in a certain society. In India, the sex ratio is calculated as the number of females per 1000 males. The sex ratio in India indicates a high level of deficit of women are missing and with a decline in the sex ratio this number is likely to increase in future. ${ }^{10}$

From the above research and fact, the researcher felt the need to assess the awareness and attitude regarding female foeticide among eligible couples at rural area of Jodhpur.

\section{OBJECTIVES OF THE STUDY}

- To assess the awareness regarding female foeticide among eligible couples.

- To determine the attitude regarding female foeticide among eligible couples.

- To correlate the awareness and attitude regarding female foeticide among eligible couples.

- To find out the association between level of awareness regarding female foeticide and socio demographic variable among eligible couples.

- To find out the association between level of attitude regarding female foeticide and socio demographic variable among eligible couples.

\section{HYPOTHESIS OF THE STUDY}

- $\quad \mathbf{H}_{\mathbf{1}}$ : There is a positive relationship between good awareness and positive attitude regarding female foeticide among eligible couples.

- $\quad \mathbf{H}_{\mathbf{2}}$ : There is significant association between the level of awareness regarding female foeticide and socio demographic variable among eligible couples.

- $\quad \mathbf{H}_{3}$ : There is significant association between the level of attitude regarding female foeticide and socio demographic variable among eligible couples.

\section{OPERATIONAL DEFINITION}

- Awareness: In this study, awareness refers to what is known about female foeticide among eligible couples and which is measured by response toward the interview schedule.

- Attitude: In this study it refers to the expressed feelings, opinions \& beliefs of eligible couples regarding female foeticide, which is measured by Likert's rating scale.

- Female Foeticide: It refers to aborting a female foetus after sex determination throughout prenatal diagnostic test.

- Eligible Couple: It refers to a currently married couples where in the wife is in the reproductive age, which is generally assumed to lie between the ages of 18-45 years.

\section{ASSUMPTION}

- Eligible couples have some awareness regarding female foeticide.

- Eligible couples have positive attitude towards female foeticide. 


\section{EPRA International Journal of Research and Development (IJRD)}

\section{DELIMITATION}

- The study is delimited to eligible couples at selected rural areas of Jodhpur.

\section{RESEARCH METHODOLOGY \\ - RESEARCH APPROACH}

A quantitative descriptive research approach is considered appropriate for the present study.

\section{- RESEARCH DESIGN}

Descriptive survey design was adopted for this study.

\section{RESEARCH VARIABLE}

\section{- Research variable}

Research variables are those variable which are observed a measured in natural setting as they exist without any manipulation in the descriptive study no last effect relationship is examined. In my study the research variables is awareness and attitude regarding female foeticide of eligible couples.

\section{- Demographic variable}

The demographic variable considered for this study were age of the husband, age of the wife, religion, type of family, education of husband, education of wife, monthly income of family, occupation of husband, occupation of wife, sources of information.

\section{POPULATION}

Eligible couples

\section{SAMPLING SIZE}

The sample selected for the present study were eligible couples with in the age group of $18-$ 45 year at village Salawas, Tehsil Luni, District Jodhpur.

Sample size is the number of observations used for calculating estimates of a given population.
In this study, the sample consists of total 100 eligible couples at village Salawas, Tehsil Luni, District Jodhpur.

\section{SAMPLING TECHNIQUE}

Non-probability purposive sampling technique was used for this study.

\section{RELIABLITY OF THE TOOL}

In order to establish the reliability of the tool, it was administered to 10 eligible couples other than study sample. The Cronbach's Alpha method was used to test the reliability of the tools. The value ' $r$ ' was 0.784 for awareness and the value of ' $r$ ' was 0.707 for attitude scale. The tool was found to be valid reliable and feasible.

\section{MAJOR FINDING OF THE STUDY}

Table 1 Depicted that of female foeticide participated in the study, age 25-31 Husband (36, $36 \%)$, Wife $(35,35 \%)$, educational status sr. sec Husband (45, 45\%), wife primary (36, 36\%), occupational status Husband private job (87, 87\%), wife none $(77,77 \%)$, religion Hindu $(81,81 \%)$, monthly income 5000-10,000 (44, 44\%), type of family nuclear $(80,80 \%)$, source of information family friend $(52,52 \%)$.

Table 2 Depicted that majority (54\%) of the sample had average awareness, followed by $29 \%$ had poor awareness and remaining (17\%) sample had good awareness regarding female foeticide.

Table 3 Depicted shows that majority (35\%) of the sample had negative attitude, followed by $28 \%$ had Positive attitude, $20 \%$ had strongly negative attitude and remaining (17\%) sample had strongly positive attitude regarding female foeticide.

Table 1. Frequency and percentage distribution of demographic variables among female foeticide

\begin{tabular}{|c|c|c|c|c|c|c|}
\hline \multirow{2}{*}{$\begin{array}{c}\text { S. } \\
\text { No }\end{array}$} & \multirow{2}{*}{\multicolumn{2}{|c|}{ Socio-demographic variable }} & \multicolumn{2}{|c|}{ Husband } & \multicolumn{2}{|c|}{$\begin{array}{r}(\mathrm{N}=100) \\
\text { Wife }\end{array}$} \\
\hline & & & Frequency & Percentage & Frequency & Percentage \\
\hline \multirow{4}{*}{1.} & & $18-24$ & 30 & $30 \%$ & 30 & $30 \%$ \\
\hline & Age & $25-31$ & 36 & $36 \%$ & 35 & $35 \%$ \\
\hline & (in years) & $32-38$ & 31 & $31 \%$ & 34 & $34 \%$ \\
\hline & & $39-45$ & 03 & $03 \%$ & 01 & $01 \%$ \\
\hline \multirow{4}{*}{2.} & \multirow{4}{*}{ Educational Status } & Illiterate & 13 & $13 \%$ & 19 & $19 \%$ \\
\hline & & Primary & 14 & $14 \%$ & 36 & $36 \%$ \\
\hline & & Sec. \& Sr. Sec & 45 & $45 \%$ & 35 & $35 \%$ \\
\hline & & Graduate & 28 & $28 \%$ & 10 & $10 \%$ \\
\hline \multirow{3}{*}{3.} & \multirow{3}{*}{ Occupational Status } & Govt. job & 2 & $2 \%$ & 0 & $0 \%$ \\
\hline & & Private job & 87 & $87 \%$ & 23 & $23 \%$ \\
\hline & & None/Other & 11 & $11 \%$ & 77 & $77 \%$ \\
\hline
\end{tabular}


EPRA International Journal of Research and Development (IJRD)

Volume: 6 | Issue: 7 | July 2021

- Peer Reviewed Journal

\begin{tabular}{|c|c|c|c|c|}
\hline \multirow[b]{2}{*}{4.} & \multirow[b]{2}{*}{ Religion } & \multirow[b]{2}{*}{$\begin{array}{l}\text { Hindu } \\
\text { Muslim }\end{array}$} & Frequency (n) & Percentage \% \\
\hline & & & $\begin{array}{l}81 \\
19\end{array}$ & $\begin{array}{l}81 \% \\
19 \%\end{array}$ \\
\hline 5. & $\begin{array}{l}\text { Monthly family } \\
\text { Income }\end{array}$ & $\begin{array}{c}5000-10000 \\
10001-15000 \\
15001-20000 \\
\text { Above } 20001\end{array}$ & $\begin{array}{l}44 \\
43 \\
11 \\
02\end{array}$ & $\begin{array}{l}44 \% \\
43 \% \\
11 \% \\
02 \%\end{array}$ \\
\hline 6. & Type of family & $\begin{array}{c}\text { Joint } \\
\text { Nuclear }\end{array}$ & $\begin{array}{l}20 \\
80\end{array}$ & $\begin{array}{l}20 \% \\
80 \%\end{array}$ \\
\hline 7. & $\begin{array}{l}\text { Source of } \\
\text { information }\end{array}$ & $\begin{array}{l}\text { Mass media } \\
\text { Family / friends } \\
\text { Health pro. }\end{array}$ & $\begin{array}{l}27 \\
52 \\
21\end{array}$ & $\begin{array}{l}27 \% \\
52 \% \\
21 \%\end{array}$ \\
\hline
\end{tabular}

Table 2. Frequency and percentage distribution of the level of awareness regarding female foeticide

\begin{tabular}{|c|c|c|}
\hline \multicolumn{2}{|c|}{ (N=100) } \\
\hline Level of Awareness & Frequency & Percentage \\
\hline Poor $(<50 \%)$ & 29 & $29 \%$ \\
\hline Average $(50-70 \%)$ & 54 & $54 \%$ \\
\hline Good $(>75 \%)$ & 17 & $17 \%$ \\
\hline Total & 100 & $100.0 \%$ \\
\hline
\end{tabular}

Table 3. Frequency and percentage distribution of the level of attitude regarding female foeticide

\begin{tabular}{|c|c|c|}
\hline \multicolumn{2}{|c|}{$(\mathbf{N}=\mathbf{1 0 0})$} \\
\hline Level of Attitude & Frequency & Percentage \\
\hline Strongly Negative & 20 & $20 \%$ \\
\hline Negative & 35 & $35 \%$ \\
\hline Positive & 28 & $28 \%$ \\
\hline Strongly Positive & 17 & $17 \%$ \\
\hline Total & 100 & $100.0 \%$ \\
\hline
\end{tabular}

\section{DISCUSSION}

The finding of the study shows that majority (54\%) of the sample had average awareness, followed by $29 \%$ had poor awareness and remaining (17\%) sample had good awareness regarding female foeticide. The awareness score of eligible couples according to the different aspects of the female foeticide was highest $(64.83 \%)$ regarding the 'Prevention of female foeticide' with the mean 3.89 and SD of \pm 0.863 , followed by $64.10 \%$ regarding the 'female foeticide' with the mean 6.41 and SD of \pm 2.370 and lowest $(51.00 \%)$ in regarding 'causes of female foeticide' with the mean 2.04 and SD of \pm 0.790 . The overall awareness score with mean $\pm \mathrm{SD}$ is $12.34 \pm 2.808$ and mean percent awareness of $61.70 \%$.

The finding of the study shows that majority $(35 \%)$ of the sample had negative attitude followed by $28 \%$ had positive attitude, $20 \%$ had strongly negative attitude and remaining (17\%) sample had strongly positive attitude regarding female foeticide. The Mean and Standard Deviation of attitude regarding female foeticide among eligible couples was Mean $=12.34, \&$ SD $=2.808$. Overall mean percentage of attitude score is $61.70 \%$ among respectively.

The calculated correlation Coefficient ' $r$ ' $=$ 0.478 and corresponding $\mathrm{p}=0.000$ that is very less than 0.05 , shows that there is highly significant positive moderate correlation between awareness and attitude score regarding female foeticide among eligible couples. It means as awareness increases their attitude also positively increases moderately.

\section{CONCLUSION}

The finding raised concerns about all aspects of female foeticide. A considerable average awareness \& negative attitude regarding female foeticide. However, the majority of the demographic variables such as age of husband, education of husband, education of wife, monthly income of family, occupation of husband, occupation of wife and source of information of the samples indicates significant association with level of awareness and attitude regarding female foeticide except age of wife, religion, and type of family. 


\section{REFERENCES}

1. Devi s, Sarin J, Nair R 2014 "Effectiveness of Public Awareness Programme on Prevention of Female Foeticide and Female Infanticide in Terms of knowledge and Attitude of Adults." Int J Nur Edu Res, Vol.2 No.126 130.http://ijneronline.com/

2. Joshi N, Bajwa A K 2012 "Existing Intergenerational Continuity and Discontinuity in Knowledge of Rural Women towards Female Foeticide." J Soci Sci Vol 30 No 161164.https://thescipub.com

3. Punam S, Ryhal P C 2012, "Studying socio economic factors affecting female foeticide in Himachal Pradesh." No 1-19.

4. Roumi D, P B, D A et al 2012 "A study to assess female foeticide in Delhi/NCR: exploring the socio economic and cultural dimension." Vol.3 No.548550. https://www.njcmindia.org

5. Climent Nisha, 2015.text book on nursing research and statistics; first edition; EMMESS medical publishers:

6. Polit and Hungler (1997), 'Nursing Research Principles \& methods', Philadelphia J. B. Lippincott

7. KHATKAR S M 2019 "a comparative study to assess knowledge and attitude regarding female foeticide among women in selected urban and rural area at Fatehabad district, Haryana." Int J Sci \& Res Vol. 8 No. 48 - 52. www.ijsr.net

8. $\quad R K$, Langer B 2018 "Awareness of prenatal sex determination and preconception and prenatal diagnostic techniques act: A comparative study among rural and urban females of reproductive age group (15-45 years) attending a tertiary care teaching hospital in North India." J Current Sci Res Vol. 4 No. 21- 25. www.jcrsmed.org 